\title{
Immunohistochemistry of the cytoskeleton in the excurrent ducts of the testis in birds of the Galloanserae monophyly
}

\author{
T. A. Aire ${ }^{1,2}$ and P. C. Ozegbe ${ }^{1}$
}

(1) Department of Anatomy \& Physiology, Faculty of Veterinary Science, University of Pretoria, Onderstepoort, South Africa

(2) Department of Preclinical Studies, School of Veterinary Medicine, St. George's University, St. George's, Grenada, West Indies

\author{
T. A. Aire \\ Email: taire@sgu.edu
}

With 6 figures and 1 table

\begin{abstract}
The presence, location and degree of immunoexpression of various microfilament (MF) and intermediate filament (IF) systems (actin, cytokeratins, desmin, vimentin) were studied in the excurrent ducts of the testis in sexually mature and active galliform (Japanese quail, domestic fowl, turkey) and anseriform (duck) birds. These proteins were variably expressed between the epithelia and periductal tissue (periductal smooth muscle cell layer and interductal connective tissue) types and between species. Variable heterogeneous co-expression of filament systems was also found in the various duct epithelia and periductal tissue types: co-expression of filament systems was the rule rather than the exception. In the duck, neither vimentin nor cytokeratin was present in any of the tissues, whereas actin and desmin (absent in the rete testis) were co-expressed in the efferent ducts and epididymal duct unit (comprising the ductus conjugens, ductus epididymidis and ductus deferens). Actin, desmin and vimentin were generally co-expressed in the rete testis, efferent ducts and epididymal duct unit of the quail, domestic fowl and turkey, with vimentin being more strongly immunoreactive than actin and desmin in the epididymal duct unit, but more weakly immunoexpressed in the efferent ducts. Cytokeratin was present and co-expressed with actin, desmin and vimentin in the rete testis, efferent ducts and epididymal duct unit of the domestic fowl and turkey, but not in the quail and duck. The periductal smooth muscle cell layer and interductal tissue co-expressed actin, desmin and vimentin variably in all birds. Luminal spermatozoa of both the turkey and duck were immunonegative for all protein systems, whereas those of the quail and domestic fowl co-expressed actin, desmin and vimentin moderately or strongly. The tissues of the reproductive tract of male birds thus contain cytoskeletal protein systems that are variably but mostly co-expressed and whose contractile ability appears necessary and sufficient for transportation through the various excurent ducts of the voluminous testicular fluid and its high sperm content, characteristic features of male avian reproduction.
\end{abstract}

Keywords : Epididymis - Ductus deferens - Intermediate filaments Immunohistochemistry - Birds (Aves: Galliformes, Anseriformes)

The authors are grateful to the Wellcome (Nigeria) Trust Fund and the University of Pretoria for grants that aided this study. P.C.O. was a Foreign Postdoctoral Fellow of the University of Pretoria, on leave from the University of Ibadan.

\section{Introduction}

Knowledge of the forces and/or contractile mechanisms that are responsible for transportation of testicular fluid, with its sperm content, down the various excurrent ducts of the testis of animals is still "surprisingly deficient" (Banks et al. 2006). Cells and tissues within and around 
these ducts of the testis have recently been studied with regard to the demonstration of their contractile characteristics in various species of mammals, including human (Achtstätter et al. 1985; Miettinen et al. 1985; Ramaekers et al. 1985; Dinges et al. 1991; Wakui et al. 1994; Rodriguez et al. 1999). In mammals, it is now well established that both epithelial cells and the investing myoid or smooth muscle cell layers of these ducts contain intermediate filaments (IFs) that are solely expressed or co-expressed in the same cell type. Reported variations have caused controversies in the interpretation of cell structure, function and ontogeny. However, valuable knowledge has accrued from these reports in mammals.

Most of the excurrent ducts of birds are incorporated in a relatively small organ, which is recognized as the epididymis or epididymal region (Lake 1957) and which is extended caudally by a long wavy ductus deferens (DD). The maze of ducts that forms this organ includes the rete testis (RET), efferent ducts (EFD), connecting ducts (CD) and epididymal duct (ED). The CD, ED and DD are, together, regarded as the epididymal duct unit (ED unit), which constitutes an organ equivalent to, but not grossly structured as, the epididymis of mammals (Tingari 1971; Hess et al. 1976; Aire 2007a). Unlike in mammals, avian testicular fluid and its suspended spermatozoa are both produced in large quantities and pass through the excurrent ducts rapidly (Clulow and Jones 1982, 1988; Aire 2007a, 2007b). Therefore, in birds, a great deal of the contractile propelling force that brings about the rapid movement of this usually voluminous product of the testis of birds might occur in both the epididymis and its caudal extension, the ductus deferens.

Except for a report on the demonstration of actin microfilaments (MFs) and desmin IFs in the epididymis of the domestic fowl (Maretta and Marettova 2004), no other reports apparently exist concerning the presence of IFs in the epithelia and periductal tissue of excurrent ducts of the testis in birds. The present study, which evaluates the types of MF and IF systems (actin, cytokeratin, desmin and vimentin) that are present in the excurrent ducts of both galliform (Japanese quail, domestic fowl, turkey) and anseriform (duck) species of birds, extends and complements previous observations made in the testis of these birds (Aire and Ozegbe 2007) with a view to contributing to the understanding of the structure and function of the reproductive organs and tracts of male birds. The term "Galloanserae monophyly" is used in the title because both the Orders Galliformes and Anseriformes are, now, considered to be closely related phylogenetically (Harshman 2007).

\section{Materials and methods}

Adult, sexually active, male birds were used in this study. Tissue samples were obtained from various zones (cranio-caudal) of the epididymides and ductus deferentes of Japanese quails (Coturnix japonica; $n=5$ ), domestic fowls (Gallus gallus domesticus; $n=5$ ), turkeys (Meleagris gallopavo; $n=5$ ) and ducks (Anas platyrhynchos; $n=6$ ). For light microscopy and immunohistochemistry, pieces of tissue were fixed, by immersion, in Bouin's fluid, for 12$24 \mathrm{~h}$.

For normal histological structure, the Bouin-fixed tissues were processed by standard conventional methods for paraffin embedment, sectioned ( $5 \mu \mathrm{m}$ thickness) and stained with haematoxylin and eosin (H\&E). For immunohistochemistry, 5- $\mu$ m-thick sections of the Bouinfixed and paraffin-embedded tissue blocks were mounted on slides precoated with polylysine, deparafinized and rehydrated. Immunostaining of slides for smooth muscle actin, cytokeratin, desmin and vimentin was performed as recommended by DakoCytomation (Denmark), the supplier of the LSAB + Kit (horseradish peroxidase) used in this study. Briefly, rehydrated tissue sections were microwaved at $750 \mathrm{~W}$ for two cycles of $7 \mathrm{~min}$ each in citrate buffer $(\mathrm{pH}$ 6 ). Thereafter, the slides were allowed to cool for $20 \mathrm{~min}$ and then rinsed in phosphatebuffered saline (PBS) containing bovine serum albumin ( $\mathrm{pH} \mathrm{7.6)}$ for $5 \mathrm{~min}$. Endogenous peroxidase activity was blocked by using hydrogen peroxide ( $3 \%$ in distilled water) for $5 \mathrm{~min}$. Smooth muscle actin (DakoCytomation; Code: M085101), cytokeratin (M082101), desmin (A0611; polyclonal) and vimentin (M072501) immunodetection was carried out at room temperature for 30 min by using the respective mouse primary antibodies at dilutions of 1:50, 1:100, 1:300 and 1:100, respectively. After being rinsed in PBS, each slide was incubated 
with ready-to-use biotinylated anti-rabbit, anti-mouse and anti-goat immunoglobulin for 15 min in a humidified chamber at room temperature. Each slide was again washed in PBS, followed by incubation in streptavidin peroxidase for another $15 \mathrm{~min}$. Reactivity was visualized, after a rinse in PBS, by applying substrate-chromogen solution (either LSAB + 3,3'-diaminobenzidine or VECTOR NovaRED) for $20 \mathrm{~s}$. Sections were counter-stained with haematoxylin. Control slides were treated identically, except that the primary antibody was replaced by bovine serum albumin.

\section{Results}

\section{Actin MFs}

In the RET epithelium, actin was immunoexpressed moderately or strongly in the quail and duck, but weakly and in scattered foci in the domestic fowl and turkey (Figs. 1, 2, Table 1). Actin activity was absent in the RET of the turkey. The ciliated cells of the epithelium of the proximal efferent duct (PED) and distal efferent duct (DED) also displayed scattered weak (in the domestic fowl, turkey and duck) to moderate (in the quail) immunoexpression for actin. The epithelium of the ED unit was weakly to moderately actin-positive in the quail and domestic fowl, absent in the turkey, but strongly positive, mainly in the middle (supranuclear) portions of the non-ciliated (NC type III) cells (Aire 1979; Aire et al. 1979) of the duck. The lamina propria was negatively stained in all ducts but the periductal myoid/smooth muscle cell layer was strongly stained in all birds, except the duck in which it was only weakly to moderately positive. Strands of cells in the interductal tissue were moderately or strongly positive. Spermatozoa in the lumen of the ducts were moderately or strongly positive for actin in the quail and domestic fowl (Fig. 1) but displayed no activity in the turkey and duck (Fig. 2).

\section{Desmin}

The RET epithelial cells were negative for desmin activity in the quail and duck but only weakly positive in the domestic fowl and turkey (Figs. $\underline{3}, \underline{4}$, Table 1 ). The non-ciliated cells of the PED were weakly or moderately positive in the domestic fowl, turkey and duck. The ED unit displayed no desmin activity in the quail and turkey, only weak activity in the domestic fowl and moderate activity in the supranuclear region of the non-ciliated (NC type III) cells of the duck.

The lamina propria was generally negatively immunoreactive but the periductal smooth muscle cell layer was strongly immunopositive for desmin in all ducts and in all birds. The interductal tissue displayed scattered strands of fibres that were moderately to strongly immunoreactive. Spermatozoa in the ducts were moderately to strongly desmin-positive in the quail and domestic fowl but negative in the turkey and duck.

\section{Vimentin}

The RET was distinctly and strongly immunoreactive for vimentin in the basolateral aspects of the epithelial cells in all birds, except for the duck in which it was absent (Figs. $\underline{5}, \underline{6}$, Table $\underline{1}$ ).

The basal part of the epithelium of the PED was moderately positive for vimentin in the quail and weakly positive only in the initial part of the duct in the domestic fowl (Fig. 5). Scattered ciliated cells were entirely moderately positive for vimentin in both the PED and DED of the quail but only weakly positive or negative in the domestic fowl and turkey. Vimentin activity was moderate to strong in the basal part of the non-ciliated cells of the epithelium of the ED unit in both the domestic fowl and turkey; this activity increased cranio-caudally (Figs. $\underline{5}, \underline{6}$ ). The quail displayed only weak vimentin activity in this duct unit. The periductal tissue was only weakly positive for vimentin in the quail and turkey. Spermatozoa in all ductal lumina were immunonegative for vimentin. 


\section{Cytokeratin}

In the domestic fowl and turkey, weak to moderate cytokeratin activity was expressed in the supranuclear region of the epithelial cells of the RET and of the efferent ducts (Fig. 6). In both birds, the sub-apical region of the non-ciliated cells of the ED unit was very weakly positive in the connecting duct, whereas activity in the other segments of the unit increased caudally, such that the more caudal ductus deferens was moderately or strongly positive for cytokeratin activity, in the subapical region of the cells. Periductal smooth muscle cell layers, interductal tissue and spermatozoa were, however, negative for cytokeratin activity in all birds.

\section{Discussion}

This study has demonstrated the presence of various MF and IFs systems in the excurrent ducts of the testis of members of the Galliformes and Anseriformes, which are now considered to constitute the Subphyly of Galloanserae. Actin MF are weakly or moderately immunoexpressed in the excurrent duct epithelium of galliform birds, but strongly in the anseriform. Conversely, actin MF is strongly expressed in the periductal smooth muscle cell layer and interductal tissue in galliforms, but weakly in the anseriform. This dichotomy appears to be Order-specific. Maretta and Marettova (2004) have not demonstrated actin MF in the epithelia of the excurrent ducts of the testis of the domestic fowl, but their findings in the periductal myoid and interductal tissue are similar to those reported here. Aire (2000) has described an unusual and obvious abundance of IFs in the cytoplasm, especially around the nuclei, of the non-ciliated (NC type III) cell (Aire et al. 1979) in the ED unit of the duck, but these are not obviously demonstrable ultrastructurally in the galliform birds. Therefore, unsurprisingly, these cells in the duck display strong actin immunoactivity in the peri- and supra-nuclear zones of the NC type III cells. The significance of the elaborate presence of the MFs and IFs, and their co-expression, in this cell type, in the duck, is not known. They remain obvious ultrastructurally in the cell in sexually quiescent and inactive male ducks (Aire 2002). In mammals, Wrobel et al. (1995) have demonstrated actin MF in mononuclear (lymphocyte and macrophage) cells within the epithelium of the bovine tubuli recti (TR) and RET but not in the epithelial cells themselves. In certain mammals, e.g. the vicuña and llama (Rodriguez et al. 1999), the periductal and interductal tissue is strongly positive for actin MF activity, as is also reported here especially in the galliform birds.

Desmin IFs were generally very weakly or negatively immunostained in the epithelia of the excurrent ducts of our birds but were clearly absent in the domestic fowl studied by Maretta and Marettova (2004). These minor differences notwithstanding, the observation in birds therefore appears to be contrary to that in the dog, in which the basolateral aspect of the epithelial cells of the RET is strongly immunoreactive for desmin IF (Wakui et al. 1994). In our birds, the lamina propria of the ducts is negative, although the periductal smooth muscle cells and interductal tissue are strongly immunoreactive for desmin IF, as also found in the epididymis of the dog (Wakui et al. 1994) and human (Palacios et al. 1993). However, desmin IF is considered to be mostly present in muscle cells (Virtanen et al. 1986).

Vimentin IF has been demonstrated strongly in the basolateral aspects of the epithelial cells of the RET in all galliform (quail, domestic fowl, turkey) but not in the anseriform (duck) birds. No previous reports exist on vimentin IFs in the excurrent ducts of birds. The dichotomy in the immunoexpression of vimentin IF in the RET epithelium between the galliform and anseriform birds, in the present study, may require further investigation. However, in mammals, Rodriguez et al. (1999) have also demonstrated vimentin IF in the epithelium of the TR and RET of the vicuña and llama. In the present study, intense (moderate to strong) immunoreaction to vimentin IF has been shown in the infranuclear region of the NC type III cells in the epithelium of the ED unit of the domestic fowl and turkey. Although basal cells are numerous in this part of the excurrent ducts of birds (Aire 2007a), they are not the main or only source of vimentin activity demonstrated in the ED unit. Basal cells of birds invariably contain bundles of compact MFs (Aire 2007a), in addition to the diffuse IFs, which, according to Georgatos (1993) form elaborate architectural patterns in the living cell, and act as a medium that connects various cytoplasmic organelles, control their distribution and integrate 
the cellular space (Lazarides 1980; Geiger 1987; Zhu et al. 1997). In mammals, vimentin IF is present in the epididymis, decreasing in immunoexpression proximo-distally (i.e. from caput to cauda epididymidis) in the human (Palacios et al. 1993) and, similarly, cranio-caudally (i.e. from caput to cauda epididymidis) in the dog (Wakui et al. 1994), as has also been observed in the birds in the present report. However, Dinges et al. (1991) have found that vimentin activity increases disto-proximally in the human tissues that they have studied, contrary to the findings of Palacios et al. (1993).

Of note, cytokeratin has been immunodetected, in precisely the same pattern, in only the excurrent ducts of the testis of the domestic fowl and turkey, in this study. No previous reports are available concerning the study of this IF in the male reproductive tract of birds. However, in mammals, cytokeratin IFs are immunoexpressed in the TR and RET epithelium of the human (Dinges et al. 1991) and of the vicuña and llama (Rodriguez et al. 1999) and in the ED of the dog (Wakui et al. 1994) and human (Dinges et al. 1991; Palacios et al. 1993). Cytokeratin and vimentin are co-expressed in the epithelial cells of the human RET (Ramaekers et al. 1985), ductuli efferentes and corpus epididymidis (Kasper and Stosiek 1989; Dinges et al. 1991). Only cytokeratin has been detected in the efferent ducts of the dog (Wakui et al. 1994). In the domestic fowl and turkey, cytokeratin is co-expressed with actin, desmin and vimentin at various levels of individual activity in the excurrent ducts. The absence of cytokeratin IFs in the excurrent ducts of other birds is intriguing. Further investigations, with other methods of fixation and sources of antibodies, may be necessary to arrive at a definitive position in this regard. However, cytokeratins have not been detected immunohistochemically in the testicular capsule and peritubular tissue of the testis of birds, including the domestic fowl and turkey (Aire and Ozegbe 2007).

In the present study, the co-expression of various systems of MF and IF occurs variably in the excurrent ducts. Thus, whereas co-expression of MF and IFs is limited to actin and vimentin in the RET epithelium of the quail and turkey, co-expression of actin and vimentin (in the quail) and of actin and desmin (in the duck) has been demonstrated in the efferent ducts. Coexpression of MF and IF systems occurs in all birds, to varying degrees and combinations, in the epithelium of the ED unit (actin and vimentin in the quail; actin, desmin, vimentin and cytokeratin in the domestic fowl; actin, vimentin and cytokeratin in the turkey; and actin and desmin in the duck). These observations on variations in IF immunoexpression are in consonance with similar observations made in myoid cell populations in the testicular capsule in mammals (Leeson and Forman 1981; Wrobel et al. 1979, 1988; Maekawa et al. 1996). The variations are considered not only to reflect species-specific differences in the degree of differentiation of the cells from fibroblasts to smooth muscle cells in the myoid layer of cells, but also to be a reflection of the finding that the smooth muscle cell is a heterogeneous cell that expresses both contractile and synthetic activities at opposite poles of the spectrum (Banks et al. 2006). Epithelial cells could conceivably show similar characteristics to those of smooth muscle cells during their differentiation and function, in addition to showing speciesspecific differences. In mammals, the co-expression of IFs has been variably reported in the excurrent ducts of the testis, within and between species (Achtstätter et al. 1985; Miettinen et al. 1985; Ramaekers et al. 1985; Dinges et al. 1991). Contrary to the observations made in the ED of mammals by Kasper and Stosiek (1989) and Palacios et al. (1993) in humans, and by Wakui et al. (1994) in the dog, cytokeratin and vimentin activities in our birds increase in intensity cranio-caudally in the ED unit. This may be a major difference between birds and mammals. However, as Wakui et al. (1994) has observed in the dog, cytokeratin and vimentin activities seem to occur in different IFs in the non-ciliated cell of the ED unit of birds, cytokeratin being subapical, whereas vimentin is essentially basal in location. Co-expression of cytokeratin and vimentin is said to be related to secretory and/or absorptive functions in the excurrent ducts of the testis of mammals (Kasper and Karston 1988; Kasper and Stosiek 1989). To what degree and the way in which these IF systems influence cellular activities in the epithelium of the various ducts remains unknown, in particular with regard to the ED unit, which displays morphological features suggestive of the merocrine type of secretory activity, in birds (Tingari 1972; Esponda and Bedford 1985; Morris et al. 1987; Aire 2000, 2007a).

Aberrant seminiferous tubules have previously been reported in the epididymis of the domestic fowl (Aire 1980). The absence of desmin IFs in the peritubular smooth muscle coat surrounding the aberrant seminiferous tubules that were fortuitously observed in the duck 
epididymis suggests that smooth muscle or myoid cells probably fail to develop and express themselves functionally in ducts that are aplastic, atrophic or degenerate. Of significance, the peritubular smooth muscle or myoid cell layer of normal seminiferous tubules of members of the Galloanserae, including the duck, has been found to be moderately desminimmunopositive (Aire and Ozegbe 2007). A paracrine relationship has been established to exist between myoid cells, Sertoli cells and general seminiferous tubule function (Skinner 1987; Skinner et al. 1991).

In conclusion, the immunoexpression of the different MF and IF systems varies in intensity between species, especially in the co-expression between the galliform and anseriform birds studied here. Unlike the members of the Galliformes, the duck fails to immunoexpress vimentin in any cell or tissue of the excurrent ducts. Moreover, the absence of cytokeratin immunoexpression in the reproductive tract of the quail and duck, unlike in the domestic fowl and turkey, may require further investigation. In birds, as has also been reported for mammals, the co-expression of two or more IF systems occurs variably in both epithelial cells and periductal smooth muscle cells. The results show that adequate contractile and regulatory proteins of the MF and IF systems occur in the epithelial and periductal tissues of the excurrent ducts of birds; these, together with the contractile cells in both the testicular capsule and boundary tissue of the seminiferous tubules (Aire and Ozegbe 2007), constitute a veritable propelling force that is capable of transporting very rapidly, through the excurrent ducts, the usually large quantities of both testicular fluid and its suspended spermatozoa, for which many members of this Order of vertebrates are now well known.

Acknowledgements The authors are grateful to St. George's University for photographic and word-processing facilities.

\section{References}

Achtstätter T, Moll R, Moore B, Eranke WW (1985) Cytokeratin polypeptide pattern of different epithelia of the human male urogenital tract: immunofluorescence and gel electrophoretic studies. Histochem Cytochem 33:415-426

Aire TA (1979) The epididymal region of the Japanese quail (Coturnix coturnix japonica). Acta Anat 103:305-312

Aire TA (1980) Aberrant seminiferous tubule portions in the epididymal region of the domestic fowl (Gallus domesticus). Poultry Sci 59:453-455

Aire TA (2000) Aspects of the functional morphology of the ductus epididymidis in domestic anseriform and galliform birds. Anat Histol Embryol 29:179-191

Aire TA (2002) Cyclical changes in the non-ciliated epithelia of the epididymis of birds. Anat Histol Embryol 31:113-118

Aire TA (2007a) Anatomy of the testis and male reproductive tract. In: Jamieson BGM (ed) Reproductive biology and phylogeny of birds, vol 6A. Science, New Hampshire Plymouth, pp 37-113

Aire TA (2007b) Spermatogenesis and testicular cycles. In: Jamieson BGM (ed) Reproductive biology and phylogeny of birds, vol 6A. Science, New Hampshire Plymouth, pp 279-347

Aire TA, Ozegbe PC (2007) The testicular capsule and peritubular tissue of birds: morphometry, histology, ultrastructure and immunohistochemistry. J Anat 210:731-740

Aire TA, Ayeni JSO, Olowookorun MO (1979) The structure of the excurrent ducts of the testis of the guinea-fowl (Numida meleagris). J Anat 129:633-643

Banks FCL, Knight GE, Calvert RC, Turmaine M, Thompson CS, Mikhalidis DP, Morgan RJ, Burnstock $G$ (2006) Smooth muscle and purinergic contraction of the human, rabbit, rat, and 
mouse testicular capsule. Biol Reprod 74:473-480

Clulow J, Jones RC (1982) Production, transport, maturation, storage and survival of spermatozoa in the male Japanese quail, Coturnix coturnix japonica. J Reprod Fertil 64:259266

Clulow J, Jones RC (1988) Studies of fluid and spermatozoal transport in the extratesticular ducts of the Japanese quail. J Anat 157:1-11

Dinges HP, Zatloukal K, Schmid C, Mair S, Wirnsbeger G (1991) Co-expression of cytokeratin and vimentin filaments in rete testis and epididymis. Virchows Archiv [A] Path Anat Histopath 418:119-127

Esponda P, Bedford JM (1985) Surface of the rooster spermatozoon changes in passing through the Wolffian duct. J Exp Zool 234:441-449

Geiger B (1987) Intermediate filaments: looking for a function. Nature 329:392-393

Georgatos SD (1993) Dynamics of intermediate filaments: recent progress and unanswered questions. FEBS Lett 318:101-107

Harshman J (2007) Classification and phylogeny of birds. In: Jamieson BMG (ed)

Reproductive biology and phylogeny of birds, vol 6A. Science, New Hampshire Plymouth, pp $1-35$

Hess RA, Thurston RJ, Biellier HV (1976) Ultrastructure of the epididymal region and ductus deferens of the turkey (Meleagris gallopavo). J Anat 122:241-252

Kasper M, Karston U (1988) Coexpression of cytokeratin and vimentin in Rathke's cysts of the human pituitary gland. Cell Tissue Res 253:419-424

Kasper M, Stosiek P (1989) Immunohistochemical investigation of different cytokeratins and vimentin in the human epididymis from the fetal period up to adulthood. Cell Tissue Res 257:661-664

Lake PE (1957) The male reproductive tract of the fowl. J Anat 91:16-29

Lazarides E (1980) Intermediate filaments as mechanical integrators of cellular space. Nature 283:249-256

Leeson CR, Forman DE (1981) Postnatal development and differentiation of contractile cells within the rabbit testis. J Anat 132:491-511

Maekawa M, Kamimura K, Nagano T (1996) Peritubular myoid cells in the testis: their structure and function. Arch Histol Cytol 59:1-13

Maretta M, Marettova E (2004) Immunohistochemical demonstration of myoid cells in the testis and its excurent ducts in the domestic fowl. Br Poult Sci 45:585-589

Miettinen M, Virtanen I, Talerman A (1985) Intermediate filament proteins in human testis and testicular germ-cell tumors. Am J Pathol 120:402-410

Morris SA, Howarth B, Crim B, de Rodriguez CS, Esponda P, Bedford JM (1987) Specificity of sperm-binding Wolffian duct proteins in the rooster and their persistence on spermatozoa in the female host glands. J Exp Zool 242:189-198 
Palacios J, Regadera J, Paniagua R, Gamallo C, Nistal M (1993) Immunohistochemistry of the human ductus epididymis. Anat Rec 235:560-566

Ramaekers FCS, Feitz W, Moeske O, Schaart G, Herman C, Debruyne F, Vooijes GP (1985) Antibodies to cytokeratin and vimentin in testicular tumour diagnosis. Virchows Arch $[A]$ Pathol Anat 408:127-142

Rodríguez A, Rojas MA, Bustos-Obregón E, Urquieta B, Regadera J (1999) Distribution of keratins, vimentin, and actin in the testis of two South American camelids: vicuña (Vicugna) and llama (Lama glama). An immunohistochemical study. Anat Rec 254:330-335

Skinner MK (1987) Cell-cell interactions in the testis. Ann N Y Acad Sci 513:158-171

Skinner MK, Norton JN, Mullaney B, Rosselli M, Whaley PD, Anthony CT (1991) Cell-cell interactions and the regulation of testis function. Ann N Y Acad Sci 637:354-363

Tingari MD (1971) On the structure of the epididymal region and ductus deferens of the domestic fowl (Gallus domesticus). J Anat 109:423-435

Tingari MD (1972) The fine structure of the epithelial lining of the excurrent duct system of the testis of the domestic fowl (Gallus domesticus). Q J Exp Physiol 57:271-295

Virtanen I, Kalljoki M, Närvänen O, Paranko LE, Miettinen M, Lehto V-P (1986) Peritubular myoid cells of human and rat testis are smooth muscle cells that contain desmin-type intermediate filaments. Anat Rec 215:10-20

Wakui S, Furusato M, Ushigome S, Kano Y (1994) Co-expression of different cytokeratins, vimentin and desmin in the rete testis and epididymis in the dog. J Anat 184:147-151

Wrobel K-H, Bickel D, Kujat R (1995) Distribution pattern of F-actin, vimentin and alphatubulin in the bovine testis during postnatal development. Acta Anat 153:263-272

Wrobel K-H, Mademann R, Sinowatz F (1979) The lamina propria of the bovine seminiferous tubule. Cell Tissue Res 202:357-377

Wrobel K-H, Dostal S, Schimmer M (1988) Postnatal development of the tubular lamina propria and the intertubular tissue in the bovine testis. Cell Tissue Res 252:639-653

Zhu LJ, Zong SD, Phillips DM, Moo-Young AJ, Bardin CW (1997) Changes in the distribution of intermediate filaments in the rat Sertoli cells during the seminiferous epithelium cycle and postnatal development. Anat Rec 248:391-405 


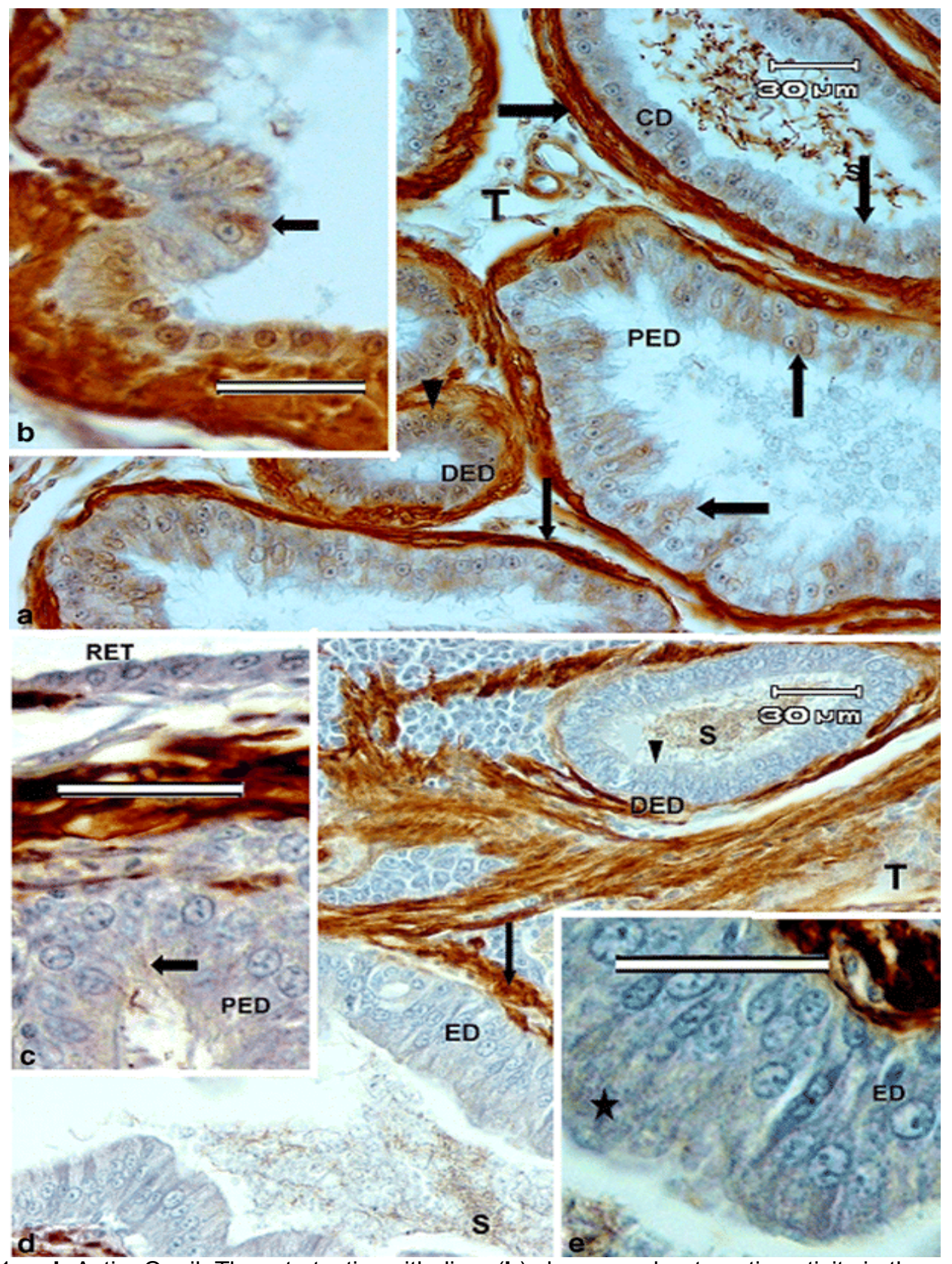

Fig. 1 a, b Actin. Quail. The rete testis epithelium (b) shows moderate actin activity in the cell. The proximal efferent ductule $(P E D)$ shows scattered weak to moderate actin activity, especially in the ciliated cells (arrows) of the epithelium $(\mathbf{a}, \mathbf{b})$. The distal efferent duct $(D E D)$ epithelium, which contains more ciliated than non-ciliated cells, is generally moderately positive (arrowhead). The non-ciliated (NC type III) cells of the epididymal duct unit (e.g. connecting duct; $C D$ ) shows weak to moderate actin activity (arrow). The periductal muscle layer (large arrow) is strongly actin-positive in all ducts, whereas scattered actin-positive profiles abound in the interductal tissue $(T)$. Spermatozoa are strongly actin-positive. c-e Actin. Domestic fowl. The rete testis (RET) epithelium displays little or no actin activity (c), but the epithelial cells of the PED (c, arrow) and DED (arrowhead) show weak actin activity, especially in their apical regions. The epididymal duct unit $(E D)$ also displays weak to moderate supranuclear actin activity (star in $\mathbf{e}$ ). The periductal muscle layer is strongly actinpositive but the interductal tissue $(T)$ is only moderately positive for actin. Spermatzoa $(S)$ in the ductal lumina are moderately actin-positive. Bars $15 \mu \mathrm{m}(\mathbf{b}, \mathbf{c}, \mathbf{e})$ 

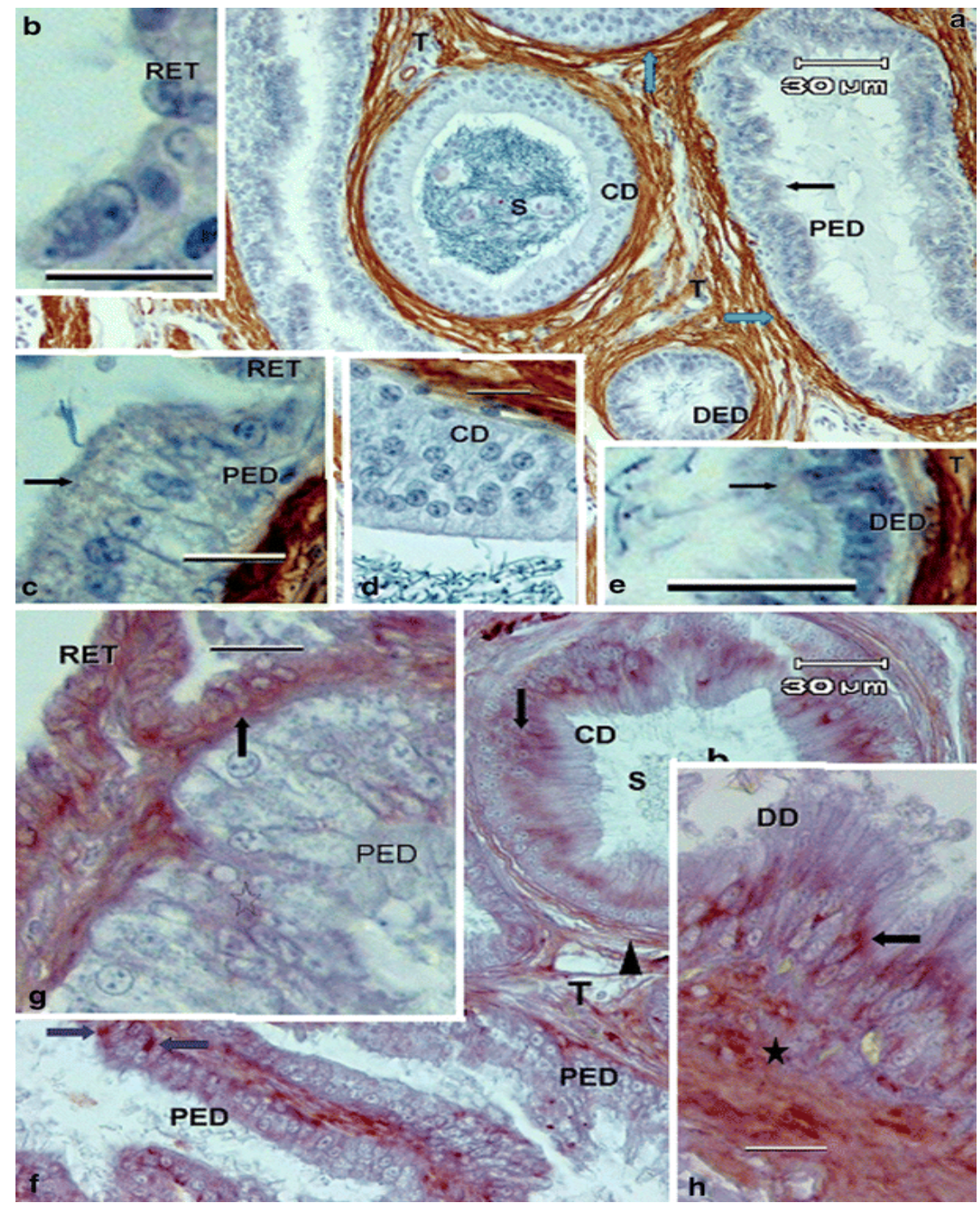

Fig. 2 a-e Actin. Turkey. The RET epithelial cells (RET in b) display no activity to actin, but the PED epithelial cells (a, c) exhibit weak supranuclear granular actin activity (black arrows). The DED epithelium shows, at best, very weak actin activity (arrow in $\mathbf{e}$ ). The epididymal duct unit (e.g. connecting duct; $C D$ in a, d) shows no activity. The periductal muscle layers (lightgreen arrows) and interductal tissue $(T)$ are strongly positive for actin. Spermatozoa $(S)$ are negatively stained for actin activity. $\mathbf{f}-\mathbf{h}$ Actin. Duck. The rete testis epithelial cells (RET in $\mathbf{g})$ display strong actin activity, basally and laterally (arrow), but not apically. The PED epithelial cells show scattered weak activity, basally and /or supranuclearly (star in $\mathbf{g}$, blue arrows in f). The epithelium of the epididymal duct unit, e.g. connecting duct ( $C D$ in $\mathbf{f}$ ) and ductus deferens ( $D D$ in $\mathbf{h}$ ) exhibits mainly moderate supranuclear and perinuclear actin activity (black arrows). Spermatozoa $(S)$ are negative for actin activity. The periductular muscle layer and interductal tissue $(T)$ are moderately actin-positive (arrowhead). Bars $15 \mu \mathrm{m}(\mathbf{b}-\mathbf{e}, \mathbf{g}, \mathbf{h})$ 
Table 1 Individual expression and/or co-expression of microfialments and intermediate filaments in the epididymis of birds of the Galloanserae monophyly ( $A$ actin, $D$ desmin, $V$ vimentin, $D D$ ductus deferens, + very weak immunoreaction, ++ weak immunoreaction, +++ moderate immunoreaction, ++++ to +++++ strong immunoreaction)

\begin{tabular}{|c|c|c|c|c|c|}
\hline \multirow{2}{*}{$\begin{array}{l}\text { Specie } \\
\text { s of } \\
\text { bird }\end{array}$} & \multicolumn{3}{|l|}{ Epithelium } & \multicolumn{2}{|c|}{$\begin{array}{l}\text { Peri- and interductal } \\
\text { tissue }\end{array}$} \\
\hline & Rete testis & $\begin{array}{l}\text { Efferent duct } \\
\text { unit }\end{array}$ & $\begin{array}{l}\text { Epididymal duct } \\
\text { unit }\end{array}$ & $\begin{array}{l}\text { Smooth } \\
\text { muscle cell } \\
\text { layer }\end{array}$ & $\begin{array}{l}\text { Interduct } \\
\text { al tissue }\end{array}$ \\
\hline Quail & $\begin{array}{l}\mathrm{A}(+ \text { to } \\
+++) / \mathrm{V}(+++++)\end{array}$ & $\begin{array}{l}\mathrm{A}(++ \text { to } \\
+++) / \mathrm{V}(++ \text { to } \\
+++)\end{array}$ & $\mathrm{A}(+$ to ++$) / \mathrm{V}(+$ to ++$)$ & $\begin{array}{l}\mathrm{A}(++) / \\
\mathrm{D}(++++) / \mathrm{V}(- \\
\text { to }+)\end{array}$ & $\begin{array}{l}\mathrm{D} \\
(++) / \mathrm{V}(+ \\
\text { to }++)\end{array}$ \\
\hline $\begin{array}{l}\text { Domest } \\
\text { ic fowl }\end{array}$ & $\begin{array}{l}\mathrm{A}(- \text { to } \\
+) / \mathrm{D}(+) / \mathrm{V}(+++++) \\
/ \mathrm{Cyt}(- \text { to }++) /\end{array}$ & $\begin{array}{l}\mathrm{A}(+) / \mathrm{D}(+) / \mathrm{V}(+) / \mathrm{C} \\
\mathrm{yt}(+ \text { to }++)\end{array}$ & $\begin{array}{l}\mathrm{A}(+ \text { to }++) / \mathrm{D}(+ \text { to } \\
++) / \mathrm{V}(++ \text { to } \\
++++) / C y t(+++)[\text { suba } \\
\text { pical }]\end{array}$ & $\begin{array}{l}\mathrm{A}(++++) / \mathrm{D}(++ \\
++)\end{array}$ & $\begin{array}{l}\mathrm{A}(++++) / \\
\mathrm{V}(-)\end{array}$ \\
\hline Turkey & $\begin{array}{l}\mathrm{A}(+) / \mathrm{V} \\
(++++) / \mathrm{D}(+) / \mathrm{Cyt} \\
(- \text { to }+)\end{array}$ & $\begin{array}{l}\mathrm{A}(+) / \mathrm{D}(++ \text { to } \\
++++) / \mathrm{V}(+) / \mathrm{Cyt}( \\
+ \text { to }++)\end{array}$ & $\begin{array}{l}V(++++) \text { [basal part } \\
\text { of ED and } \\
\text { DD]/Cyt(+++)[subapi } \\
\text { cal] }\end{array}$ & $\begin{array}{l}\mathrm{A}(+++++) / \mathrm{D} \\
(+++++) / \mathrm{V} \\
(+++)\end{array}$ & $\begin{array}{l}\mathrm{A}(+++) / \mathrm{D} \\
(+ \text { to } \\
+++++) / \mathrm{V} \\
(+)\end{array}$ \\
\hline Duck & $\mathrm{A}(+++++)$ & $\begin{array}{l}\mathrm{A}(+ \text { to }+++) / \mathrm{D}(+ \\
\text { to }++)\end{array}$ & $\begin{array}{l}\mathrm{A}(+++ \text { to }++++) / \mathrm{D} \\
(+++)\end{array}$ & $\begin{array}{l}\mathrm{A}(+ \text { to }+++) / \mathrm{D} \\
(+++)\end{array}$ & $\begin{array}{l}\mathrm{A}(+ \text { to } \\
+++) / \mathrm{D}(+ \\
\text { to }+++)\end{array}$ \\
\hline
\end{tabular}




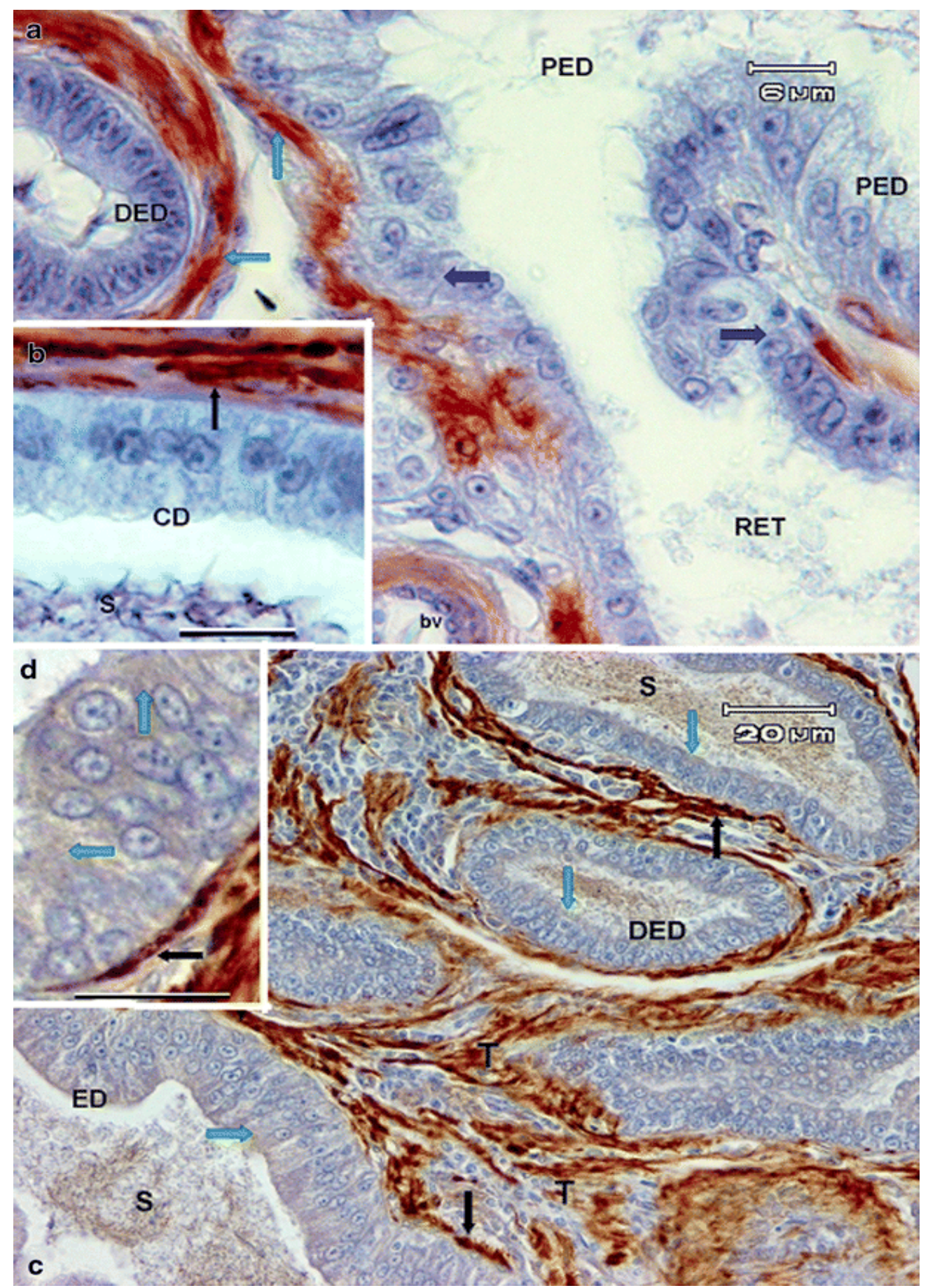

Fig. 3 a, b Desmin. Quail. The epithelium (in a) of neither the RET nor efferent ducts (both PED and DED) is positive for desmin activity (dark arrows junction between RET and PED). The epithelium of the epididymal duct unit represented by the connecting duct $(C D$ in $\mathbf{b})$ is also desmin-negative. Desmin activity in the periductal smooth muscle cell layers of all ducts is, however, strongly positive (black arrow), and spermatozoa $(S)$ in the connecting duct ( $C D$ in b) are moderately desmin-positive ( $b v$ artery). c, d Desmin. Domestic fowl. The epithelium of all ducts exhibited weak desmin activity, especially in the subapical region of the cells (green arrows). The periductal smooth muscle cell layers of all ducts are strongly positive for desmin activity (black arrows). The interductal tissue $(T)$ is also strongly desmin-positive.

Spermatozoa (S) are moderately desmin-positive. Bars $15 \mu \mathrm{m}(\mathbf{b}), 10 \mu \mathrm{m}(\mathbf{d})$ 


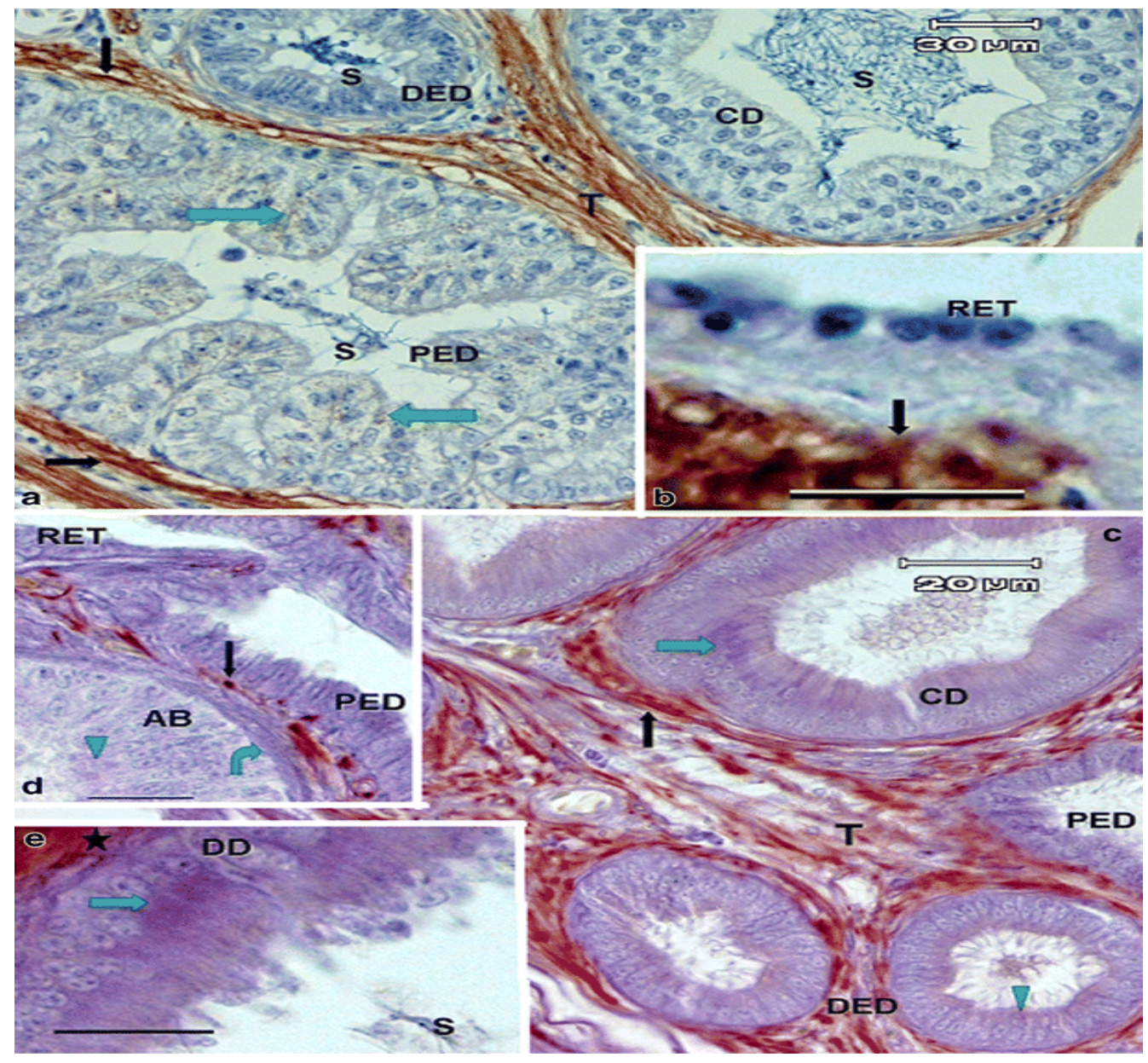

Fig. 4 a, b Desmin. Turkey. The epithelial cells of the RET (RET in $\mathbf{b}$ ) are very weakly positive or negative for desmin activity and the non-ciliated (NC type III) cells of the PED are weakly to moderately positive for desmin activity (light-green arrows in a). Desmin activity is negative in the epithelium of both the DED and epididymal duct unit (e.g. collecting duct; $C D$ in a). The periductal smooth muscle cell layer (black arrows) is moderately to strongly desmin-positive in all ducts. Spermatozoa (S) are desmin-negative. c-e Desmin. Duck. d The epithelium of both the RET and PED is devoid of desmin activity, but the Sertoli cells of the aberrant seminiferous tubule $(A B)$ show very weak activity (green arrowhead). The ciliated cells of the DED show weakly subapical desmin activity (green arrowhead in c). The epithelium of the epididymal duct unit, e.g. connecting duct ( $C D$ in $\mathbf{c}$ ) and ductus deferens $(D D$ in $\mathbf{e})$, displays (immediately supranuclearly) moderate desmin activity (green arrows) that dissipates progressively towards the apical surface of the cells. The periductal smooth muscle cell layer is moderately to strongly desmin-positive (in patches) in all ducts, except in the ductus deferens $(D D)$ in which the thick muscle layer is strongly and compactly desminpositive (star in e). The interductal tissue $(T)$ is also moderately positive for desmin activity, but in patches. The peritubular smooth muscle cell layer (curved green arrow) of the aberrant seminiferous tubule $(A B$ in $\mathbf{d})$ is desmin-negative. Spermatozoa $(S)$ in the ductus deferens $(D D$ in $\mathbf{e})$ are desmin-negative. Bars $15 \mu \mathrm{m}(\mathbf{b}, \mathbf{d}), 10 \mu \mathrm{m}(\mathbf{e})$ 


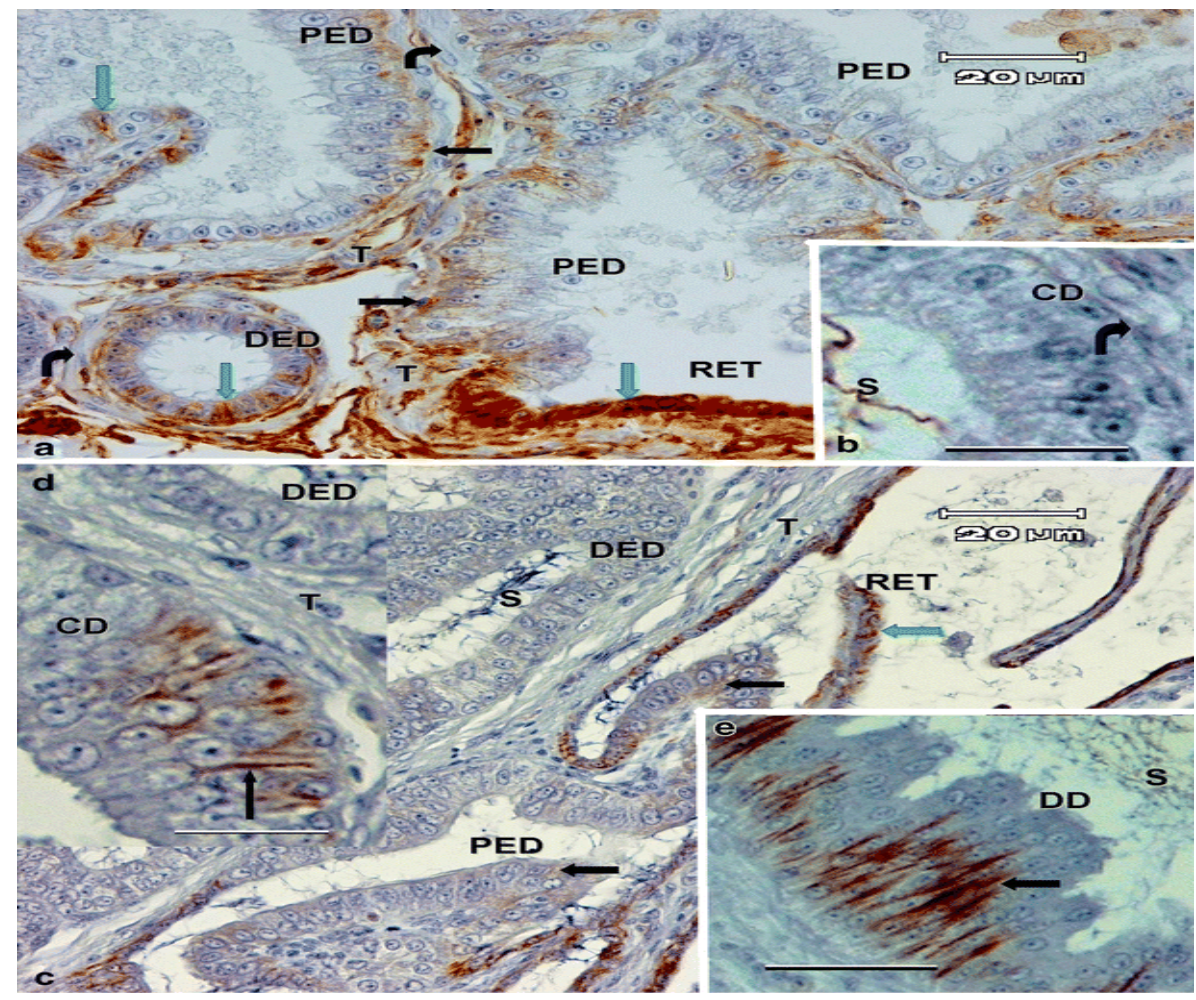

Fig. 5 a, b Vimentin. Quail. a RET epithelium $(R E T)$ is strongly positive for vimentin activity (green arrow), but the PED epithelium exhibits moderate predominantly basal activity (black arrows). A few ciliated cells (green arrows) are entirely and moderately vimentin-positive in both the PED and DED. Scattered profiles in the interductal tissue $(T)$ show strong positive activity but the periductal smooth muscle cell layers of all ducts (curved arrows) are weakly positive or negative for vimentin activity. Spermatozoa $(S)$ are moderately to strongly vimentin-positive (b). c-e Vimentin. Domestic fowl. RET epithelium (RET) displays strong vimentin activity in the basal and lateral parts of the cell cytoplasm (green arrow in c). PED epithelium is negative for vimentin activity, except in the initial parts of the PED adjoining the RET, which shows some weak vimentin activity (black arrows). The DED epithelium, periductal smooth muscle cell layers and interductal tissue $(T)$ display no activity. The epithelial cells of the epididymal duct unit, e.g. of the connecting duct $(C D)$ and ductus deferens $(D D$ in $\mathbf{e})$ show moderate to strong vimentin activity in the basal half of the cytoplasm (arrows in d, e). Spermatozoa $(S)$ in the ductus deferens $(D D)$ are weakly vimentinpositive. Bars $10 \mu \mathrm{m}(\mathbf{b}, \mathbf{d}, \mathbf{e})$ 


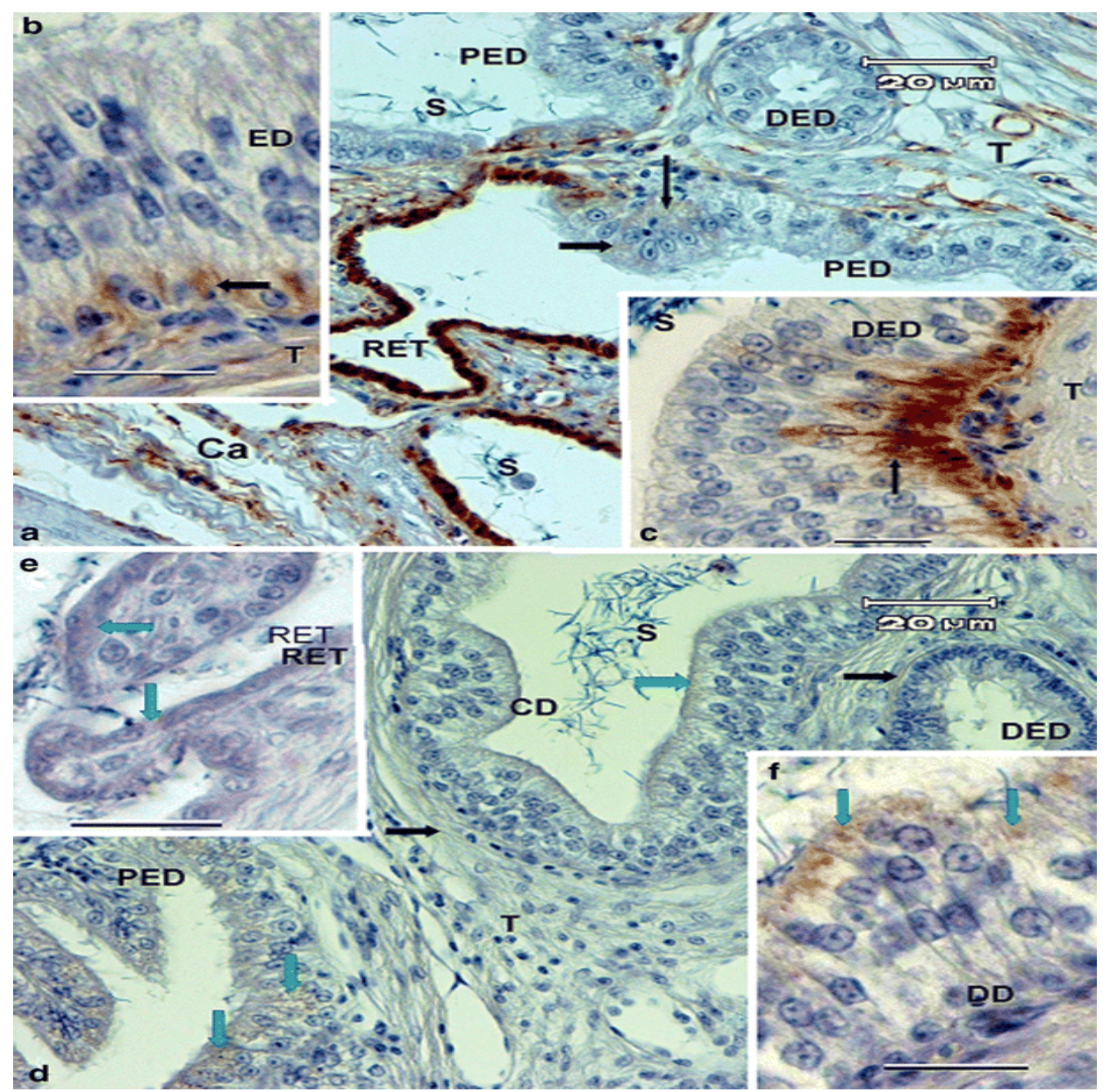

Fig. 6 a-c Vimentin. Turkey. a RET epithelial cells $(R E T)$ are strongly vimentin-positive, especially in the basal and lateral cytoplasm. Both the PED and DED epithelia exhibit, at best, scattered weak cytoplasmic vimentin activity (black arrows). The epididymal duct unit, e.g. the epididymal duct itself ( $E D$ in $\mathbf{b}$ ) and the ductus deferens (c) show moderate to strong vimentin activity in the basal infranuclear cytoplasm. This activity increases cranio-caudally, being weakest in the connecting duct, and strongest in the ductus deferens. The subapical part of the cells is either negative or very weakly positive for vimentin activity. The periductal smooth muscle cell layer and interductal tissue ( $T$ ) display negative to weak activity in strands of tissue. The epididymal capsule $(\mathrm{Ca})$ shows scattered strands of wavy vimentin-positive tissue. Spermatozoa $(S)$ are vimentin-negative. $\mathbf{d}-\mathbf{f}$ Cytokeratins. Domestic fowl. Only the epithelial cells of the rete testis (RET, green arrows in $\mathbf{e}$ ) and non-ciliated cells of the PED (green arrows in d) show weak to moderate cytokeratin activity. The epithelium of the epididymal duct unit, e.g. connecting duct $(C D)$, shows very weak subapical activity (green arrow) but that of the ductus deferens $(D D$ in $f)$ shows moderate to strong cytokeratin activity in the subapical region of the cells (green arrows). The periductal smooth muscle cell layers (black arrows), interductal tissue $(T)$ and spermatozoa $(S)$ are negative for cytokeratins. Bars $10 \mu \mathrm{m}$ (b, c, e, f) 